\title{
Contribution to mites of the genus Dermanyssus De Geer distributed in Japan (Acarina, Mesostigmata)
}

\author{
Kimito L'chikaWA* and Mamoru Takahashi** \\ * Department of Parasitology, Shinshu University School of Medicine, Matsumato 390, Japan \\ ** Kaz'agoe Senior High School, Kawagoe 350, Japan
}

(Received: February 23, 1985)

Key words: allotype, Dermany'ssus nipponensis, redescription, Dermanj'ssus grochoiskae. Japanese green woodpecker.

\begin{abstract}
A male of Dermanyssus nipponensis newly found on Picus azeokera awokera was designated as the allotype, and was described and figured. Dermanyssus grochorskae, the second species infesting the above woodpecker, was recorded as the fourth species of the genus distributed in Japan, and its detailed morphology was given with the Japanese name. Kitsutsuki-sashi-dani.
\end{abstract}

Mites of the genus Dermanyssus De Geer are obligatory blood-sucking parasites infesting birds. The two cosmopolitan species of the genus, D. gallinae (De Geer) and D. hirundinis (Hermann), are well known to occur in Japan and to bite man frequently (Asanuma, 1965; Uchikawa and Itoh, 1969). The third Japanese mite represented by only a single female specimen bears so remarkable morphological properties that it has been dealt with as the distinct species, $D$. nipponensis Uchikawa and Kitaoka, 1981.

The junior author collected some 40 mites from 2 individual birds of Picus awohera aie'okera Temminck, which had been accidentally killed and found at Mt. Myogi, Gunma Pref. The mites comprize a male of $D$. nipponensis, and a male, 41 females and a deutonymph of $D$. grochorskae Zemskaya. The male of $D$. nipponensis is new to science and $D$. grochouskae is new to Japan, that is, the fourth species of the genus distributed in this country. So the

* 内川公人：信州大学医学部奇生虫学教筑（干390 松本市坥 3-1-1)

**高橋 守：埼玉目立川越高等学校（干350 川越市 郭町 2 の) description and redescription of both the species are made below. Measurements in text are given in $\mu \mathrm{m}$ and all figures but for Fig. 11 are depicted in the same scale.

\section{Dermanys8us nipponensis Uchikawa and Kitaoka \\ [Japanese name: Aogera-sashi-dani]}

Male (Figs. 1-3). Idiosoma elongate oval, 710 long by 410 wide. Peritreme extending to coxa I. Dorsal shield broadly rounded posteriorly, bearing 17 pairs of conspicuous setate, inclusive of $J_{5}$, and an additional seta unilaterally close to $z_{1}$, lacking $s_{1}$, and 665 long and 345 wide at level of stigmata; scaling on the shield smooth as in female. About 14 pairs of stout setae on soft integument.

Venter as in Fig. 2. Holoventral shield 560 long and 133 wide at level of first gastric setae. Adanal setae slightly posterior to mid-level of anal valves; postanal seta apart from posterior margins of anal valves. About 11 pairs of setae ventrally on soft integument.

Chelicerae as in Fig. 3. Legs slender and leg chaetotaxy as follows: 

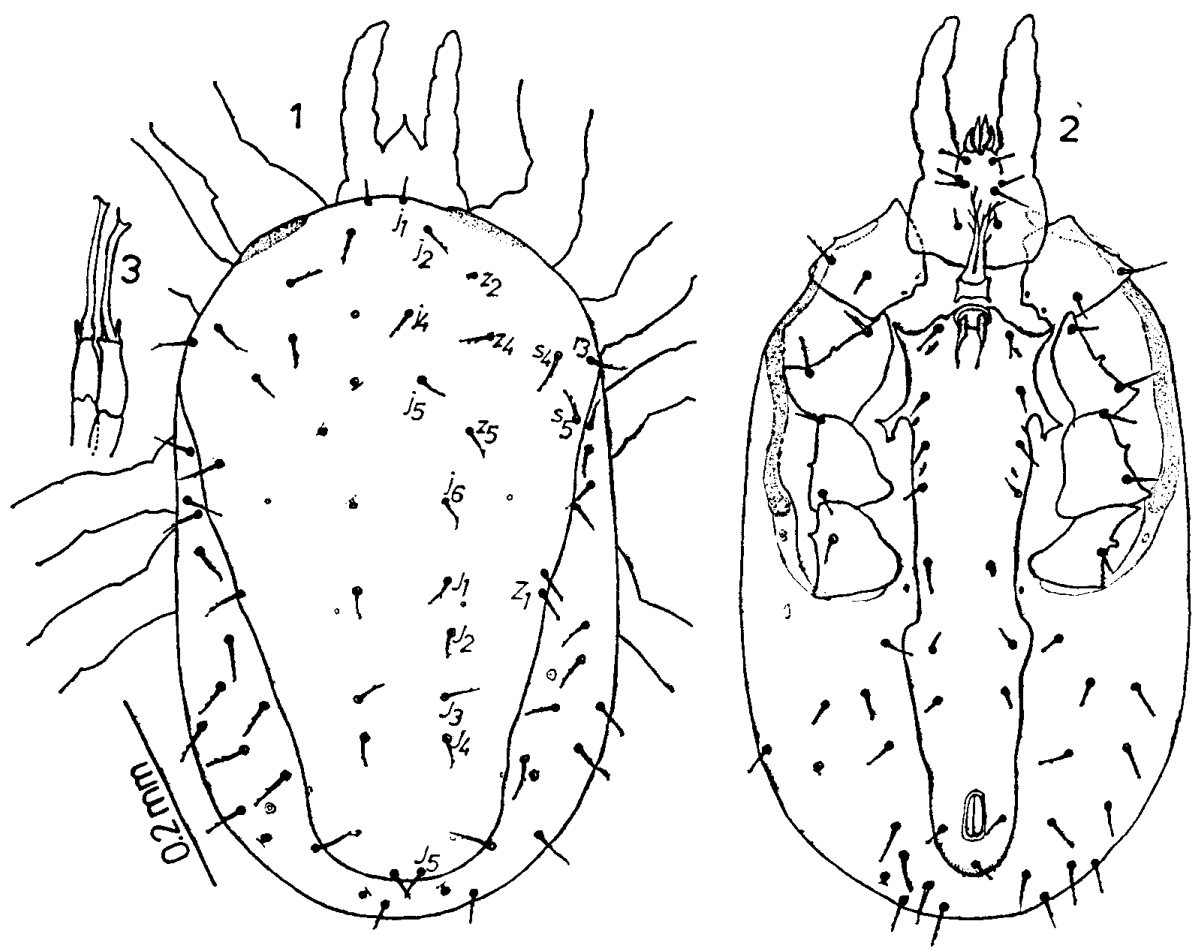

Figs. 1-3 Dermanyssus nipponensis Uchikawa and Kitaoka, male. 1: dorsum, 2: venter, 3 : chelicerae.

$$
\begin{aligned}
& \text { Femur Genu Tibia } \\
& \text { I } \quad 2-3 / 1^{-}{ }^{2} / 2^{-2} \quad 2-3 / 2^{-3} / 1^{-2} \quad 2-3 / 2^{-3} / 1^{-2} \\
& \text { II } \quad 2-^{3} / 1^{-}{ }^{2} / 2^{-1} \quad 2-3 / 1^{-2} / 1^{-2} \quad 2^{2} / 1^{-}{ }^{2} / 1^{-2} \\
& \text { III } \quad 1-2 / 1^{-1} / 0^{-1} \quad 2-{ }^{2} / 1^{-}{ }^{2} / 0^{-2} \quad 2-1 / 1^{-}{ }^{2} / 1^{-2} \\
& \text { IV } \quad 0-2 / 2^{-1} / 0^{-1} \quad 2-{ }^{2} / 1^{-3} / 0^{-1} \quad 2-1 / 1^{-3} / 1^{-2}
\end{aligned}
$$

Material examined. Allotype male ex $P$. awokera awokera, Mt. Myogi (alt. 1,100 m), Shimonita-machi, Kanra-gun, Gunma Pref., 1980-XII-19.

Remarks. D. nipponensis has been defined on the basis of only the female holotype as the mite bearing very long peritreme that extends to anterior margin of coxa I and 3 pairs of antero- and postero-dorsal setae, $a d_{1-3}$ and $p d_{1-3}$ ' on tibia I (Uchikawa and Kitaoka, 1981). Adding to these remarkable properties, $D$. nipponensis is distinct in lacking setae $s_{1}$ on dorsum in both the sexes. Existence of $s_{1}$ was recorded as not being ascertained in the original description (Uchikawa and Kitaoka, 1981), since it was hesitated to declare based only on a single female specimen that the setae were missing on dorsum of $D$. nipponensis un- paralleled with all the known species of the genus as depicted in Evans and Till (1962), Nelson and Furman (1967) and Moss (1968, 1978) up to that time. The newly found male as well as the holotype female reveals that the setae are missing in $D$. nipponensis.

Setations on dorsal surface of genua IV and tibiae IV are bilaterally asymmetric on the holotype female of $D$. nipponensis (Uchikawa and Kitaoka, 1981). The allotype male elucidates a proper setal formula each for genu IV and tibia IV as given above, which has been recorded unilaterally on the holotype.

The holotype and allotype will be deposited in the collection of the National Science Museum (Nat. Hist.), Tokyo.

\section{Dermanyssus grochovskae Zemskaya [Japanese name: Kitsutsuki-sashi-dani]}

Male (Figs. 4-6). Idiosoma oval, 555 long by 360 wide. Peritreme not reaching to anterior margin of coxa II. Dorsal shield broadly rounded anteriorly and truncated posteriorly, with weakly concave postero- 


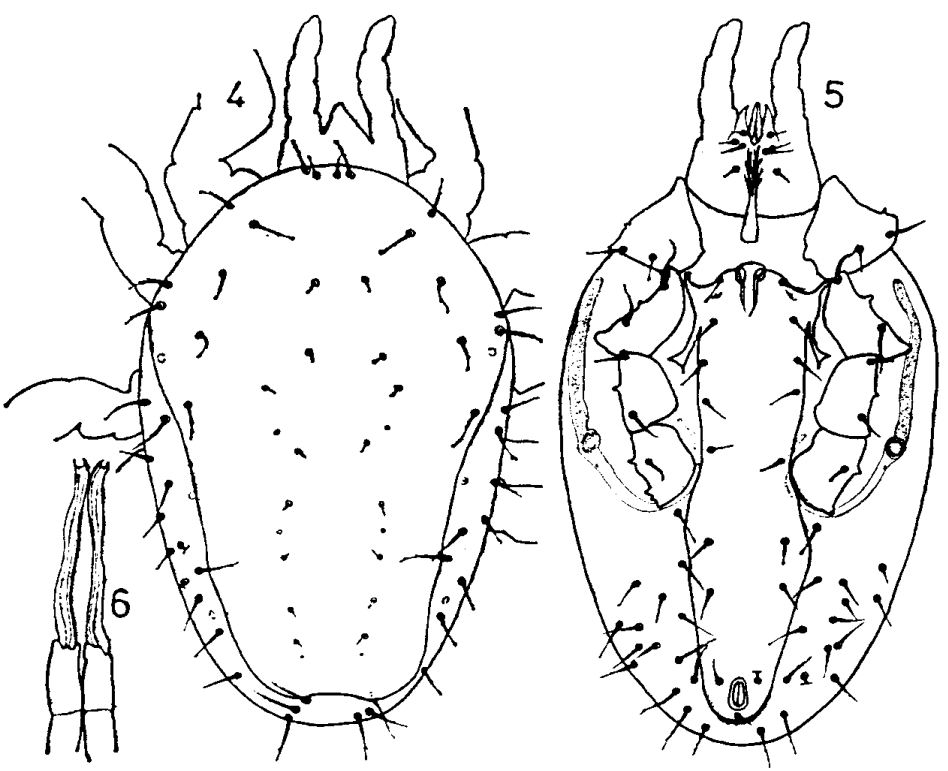

Figs. 4-6 Dermanyssus grochovskae Zemskaya, male. 4: dorsum, 5: venter, 6: chelicerae.

lateral margins and 17 pairs of setae, inclusive of $s_{1}$; antero-marginal setae on the shield distinctly longer than submedian setae; $J_{5}$ conspicuous and off the shield. About 12 pairs of fine setae, inclusive of $J_{5}$, on soft integument.

Holoventral shield 460 long and 123 wide at level of first gastric setae; setae on the shield fine; adanal setae almost on anterior level of anal valves and postanal seta close to posterior margin of anal valves. About 14 pairs of fine and long setae ventrally on soft integument.

Chelicerae as in Fig. 6; spermadactyl stout and long. Legs robust; chaetotaxy as in female.

Female (Figs. 7-11). Measurements are given as means and, in parentheses, ranges of 5 specimens. Idiosoma 745.0 (710-780) long by 487.0 (450-510) wide. Peritreme not reaching to anterior margin of coxa II. Dorsal shield $697.4(682-710)$ long by 430.2 (410-462) wide, almost oval in shape but with weakly truncated posterior margin, bearing 14 pairs of setae; 6 pairs of anteromarginal setae long and all submedian setae minute; humeral pore extero-posteriad from $s_{4}$; scaling on the shield as in Fig. 11. Paired duct-like structure present beneath dorsal shield at level of coxae IV. About 11 pairs of conspicuous setae dorsally on soft integument posterior to legs IV.
Sternal shield bearing 2 pairs each of setae and pores. Genito-ventral shield 196.0 (180-210) long posterior to genital setae and $129.6(125-135)$ wide at level of the setae. Anal shield 129.0 (125-135) long and 121.2 (120-123) wide; adanal setae on slightly posterior level of anterior margin of anal valves.

Legs slender; chaetotaxy as follows:

$$
\begin{aligned}
& \text { Femur Genu Tibia } \\
& \text { I } \quad 2{ }^{3} / 1^{-}{ }^{2} / 2^{-2} \quad 2-^{3} / 2^{-2} / 1^{-2} \quad 2-^{2} / 1^{-}{ }^{2} / 1^{-2} \\
& \text { II } 2-3 / 1^{-2} / 2^{-1} \quad 2-2 / 1^{-2} / 1^{-2} \quad 1-1 / 1^{-2} / 1^{-1} \\
& \text { III } \quad 1-{ }^{2} / 1^{-1} / 0^{-1} \quad 2-{ }^{1} / 1^{-}{ }^{2} / 0^{-2} \quad 1-1 / 1^{-}{ }^{2} / 1^{-1} \\
& \text { IV } 1-2 / 1^{-1} / 0^{-1} \quad 2-{ }^{2} / 1^{-2} / 0^{-1} \quad 1-1 / 1^{-}{ }^{2} / 1^{-1}
\end{aligned}
$$

Material examined. One $\hat{o}, 41 \% \circ$ and 1 deutonymph from the same host as that for the allotype male of $D$. nipponensis as recorded above.

Remarks. The Japanese female specimens are slightly larger than those measured in the original description by Zemskaya (1961). And outline of the dorsal shield of female differs from one another in Zemskaya (1961), Moss (1968) and in the present redescription. There is, however, no reason to separate the Japanese mite from $D$. grochovskae Zemskaya.

D. grochovskae is separable from all the 


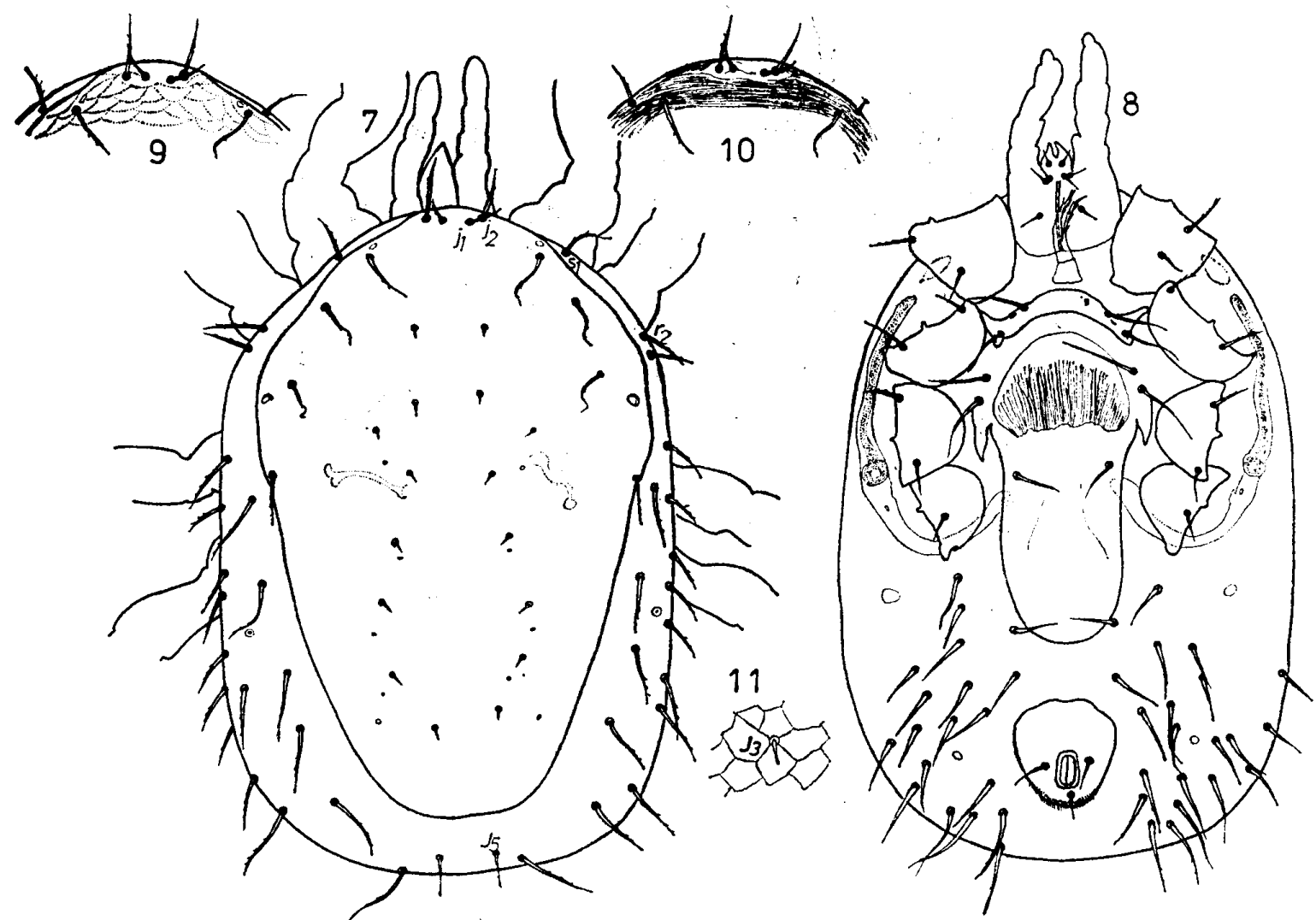

Figs. 7-11 Dermanyssus grochozskae Zemskaya, female. 7: dorsum, 8: venter, 9: antero-dorsal surface of idiosoma, 10: annulation just beneath antero-dorsal surface of idiosoma, 11: scaling on dorsal shield.

known species of the genus by its larger and oval dorsal shield bearing short submedian setae in the female. Although setae $j_{1}$ and $j_{2}$ are situated on the dorsal shield in fig. 1 in the original description (Zemskaya, 1961), these setae were observed to be situated off the shield by Moss (1968). And, indeed, anterior demarcation of dorsal shield with or without setae $j_{1}$ and $j_{2}$ is adopted as couplet 2 in his key to the females of the genus Dermanyssus to separate $D$. hirsutus and $D$. grochovskae from $D$. quintus (Moss, 1968). A close examination of the anterior part of dorsal shield reveals that the shield including setae $j_{1}$ and $j_{2}$ on it covers completely the anterior part of idiosoma, and that anterior-most part of the shield is very weakly striated as depicted in Fig. 9. The remarkable annulation as in Fig. 10, which may easily be taken for annulate soft cuticle, appears just beneath the dorsal shield. An analogous, false surface structure has also been observed in the other mesostigmatid mite, Spinturnix psi (Kolenati) (Uchikawa and Wada, 1979).

In the male, the broad dorsal shield with truncated posterior margin and relative lengths of submedian setae and anteromarginal ones are characteristic of $D$. grochouskae.

Zemskaya (1961) recorded 2 phylogenetically different birds from the Maritime Territory, the woodpecker, Dendrocopus leucotes ussuriensis, and the nutcracker, Nucifraga caryocatactes, as the hosts of $D$. grochovskae. Nelson and Furman (1967) clearly suggested a host preference of mites of the genus Dermanyssus through close observation of host range of their $D$. faralloni, and mentioned that the mite preferred birds using a covered nesting site. It is reasonable to presume that $D$. grochovskae infests woodpeckers distributed in Japan, which use nesting sites similar to that of $P$. awogera awogera. So the Japanese name, Kitsutsukisashi-dani, is given for the mite. 


\section{RefERENCES}

Asanuma, K. (1965): Family Dermanyssidae Kolenati, 1859 (suborder Mesostigmata). In: Mites-An introduction to classification, bionomics and control of Acarina (ed., Sasa, M.), pp. 74-77. University of Tokyo Press, Tokyo. (In Japanese)

Evans, G. O. and W. M. Till (1962): The genus Dermanyssus De Geer (Acari: Mesostigmata). Ann. Mag. Nat. Hist. ser. 13, 5: 273-293.

Moss, W. W. (1968): An illustrated key to the species of the acarine genus Dermanyssus (Mesostigmata: Laelapoidea: Dermanyssidae). J. Med. Entomol., 5: 67-84.

Moss, W. W. (1978): The mite genus Dermanyssus: A survey, with description of Dermanyssus trochilinis, n. sp., and a revised key to the species (Acari: Mesostigmata: Dermanyssidae). Ibid., 14: 627-640.

Nelson, B. C. and D. P. Furman (1967): A new species of Dermanyssus from marine birds, with observations on its biology (Acarina: Dermanyssidae). Acarologia, 9: 330-337.

Uchikawa, K. and H. Itoh (1969): Morphology and medical significance of Dermanyssus hirundinis (Japanese name: Suzume-sashi-dani) in Nagoya City, Japan. Ann. Rep. Nagoya City.
Health Res. Inst., 16: 103-106. (in Japanese)

Uchikawa, K. and S. Kitaoka (1981): Dermanyssus nipponensis sp. nov, taken from Japanese green woodpecker indigenous to Japan (Acari: Mesostigmata). Natl. Inst. Anim. Health $Q$. (Jpn.), $21:$ 80-82.

Uchikawa, K. and Y. Wada (1979): Studies on mesostigmatid mites parasitic on mammals and birds in Japan. IX. Bat mites of the genus Spinturnix von Heyden, 1829 (Part I) (Spinturnicidae). Jpn. J. Sanit. Zool., 30: 121-125.

Zemskaya, A. A. (1961): A new species of bird mites, Dermanyssus grochovskae Zemskaya sp. n. Zool. Jhur., 40: 134-136. (in Russian with English summary)

\section{摘 要}

日本産ワクモ属について（ダニ目ワクモ科）

これまでに本邦産のワクモ属のダニとして,ワクモ， スズメサシダニ，アオゲラサシダニの 3 種が知られて いた.アオゲラサシダニは雌模式標本だけが得られて いたにすぎなかったが，今回アオゲラから雄 1 個体が 採集されたので，それを副模式標本として記載をおこ なった. 同時に多数の Dermanyssus grochovskae が 得られたので, 雌雄を再記載し, 和名キッッキサシダ ニを与えた。 